\title{
THE RELATIONSHIP BETWEEN ECONOMIC GROWTH AND HAPPINESS
}

\author{
DOI: 10.17261/Pressacademia.2021.1531 \\ PAP- V.14-2021(53)-p.175-177
}

Adina Viorica Rus ${ }^{1}$, Alexandrina Gabriela Blăjan ${ }^{2}$

${ }^{1}$ Babes Bolyai University, Faculty of Economics and Business Administration, Cluj Napoca, Romania. adina.rus@econ.ubbcluj.ro, ORCID: 0000-0003-2295-0851

${ }^{2}$ Secondary School Gârbău, Department of Languages and Communication, Gârbău, Cluj County, Romania. alexandrina.gabriela.blajan@scoalagarbau.ro

\section{To cite this document}

Rus, A.V., Blăjan, A.G., (2021). The relationship between economic growth and happiness. PressAcademia Procedia (PAP), 14, 175-177. Permanent link to this document: $\mathrm{http}: / /$ doi.org/10.17261/Pressacademia.2021.1531

Copyright: Published by PressAcademia and limited licensed re-use rights only.

\begin{abstract}
Purpose- The purpose of this study is to analyze the relationship between economic growth (or economic performance) and happiness (life satisfaction, well-being). Happiness economics is a very contemporary research field, attracting economists, sociologists, psychologists and other scientists to investigate it, yet there is many rooms for exploration. Money is not everything, so how much does it matter precisely? This debate has divided the researchers in two parties: the ones who are arguing that economic growth and happiness go hand in hand and the ones who say that there is no relationship between these two concepts and because of this fact the constant aspiration for economic growth lost its meaning, and does more harm than benefit.

Methodology- We started by analyzing the accurate and detailed definition of the GDP and include information about it in order to better understand its function and applicability. In the following, we have analyzed the concept of happiness, the way it can be defined and measured. Then, we have analyzed the given economic theories which relate to these two concepts and describe a relationship between them. We analyzed four countries (Denmark, Costa Rica, Romania, and India) mostly based on their economic and well-being situation, and the available indicators which have an effect on well-being. We examined these countries because two of them had a very high level of wellbeing, one had a medium level and one had a low level of well-being. There were examples where the money had a good effect on happiness and also where not. In Denmark and Costa Rica money was not the only (or any reason) because for the high level of well-being, other factors, not really related to money, were high as well. In Romania, the GDP and happiness have increased at the same time. In India, the increasing GDP has brought in fact diminishing happiness.

Findings- In our paper, we have found out that there are various theories built upon this question, as controversial studies and opinions. Some researchers say that GDP has no effect on the level of well-being. On the contrary, more recent studies generally prove the other side, that GDP and happiness go hand in hand. There was one common factor in almost every research: money has a diminishing marginal utility on happiness, for a very poor country additional income does bring a high level of happiness, but for a very rich country it is almost invisible. It needs to be mentioned that growth and development do not concern just quantitative increases in production, consumption, income, or any other measures. They generally also involve qualitative changes, like education, healthcare, or political freedom. These factors certainly develop the level of well-being in a country, and for their development, there is a need for economic growth. On the other hand, economic growth does not guarantee the development of these factors, as we can see in the example of India. In my opinion, the best approach is not to focus on economic growth anymore, but on the question, how could we use this growth in GDP in order to improve our conditions and make people happier?

Conclusion- Meanwhile measuring happiness is much more complex, although we have many measures trying to assess it: Gross National Wellbeing, Happiness Index, Genuine Wealth Index Happy Planet Index, OECD Better Life Index, Human Development Index, Well-being index, Social Development Index, and many others, but they are not widely accepted because of their subjectivity and non-accuracy. Even more, it is much more difficult to improve these measures in a country because they depend on many factors, some of which are not even entirely clarified than to improve GDP, which relies on objective, strictly numerical measures.

The starting point of nearly every happiness and welfare measure is self-reported happiness, which given its nature is very subjective. This fact again provokes skepticism and antipathy in many people's minds and tends to state that these measures are not relevant and should not be based upon. Economic growth is one indicator that is widely used and analyzed, but happiness indicators are not so frequently discussed. On the other hand, we think there is a need to do it, that is why there is an emerging interest among researchers towards it.
\end{abstract}

Keywords: Economic growth, GDP, happiness, well-being, life satisfaction

JEL Codes: E71, F43, O57 


\section{REFERENCES}

Ahuvia, Aaron; Friedman, Douglas (1998). Income, consumption, and subjective well-being: toward a composite macromarketing model. Journal of Macromarketing 18(2): 153-168. http://hdl.handle.net/2027.42/69015

Bureau of Economic Analysis. (2019). Measuring the Economy: A Primer on GDP and the National Income and Product Accounts.

Causa, O., Serres, A. d., \& Ruiz, N. (2016). Growth and inequality: a close relationship? OECD.

Causa, Orsetta, Alain de Serres, Nicolas Ruiz (2014), Can growth-enhancing policies lift all boats? An analysis based on household disposable incomes. OECD Economics Department Working Paper, OECD Publishing, Paris.

Chadeau, A. (1992). What is households' non-market production worth? OECD economic studies.

Clark, A. W., \& Senik, C. (2011). Will GDP growth increase happiness in developing countries? In Robert Peccoud (Ed.), Measure For Measure: How Well Do We Measure Development?, Paris: STIN, 2011, 99-176

Costanza, R., Hart, M., Kubiszewski, I., \& Talberth, J. (2016). A short history of GDP: moving towards better measures of human well-being. thesolutionsjournal.com.

Cuijpers, R. (2011). GDP and happiness: gross national happiness, the new GDP? LAP LAMBERT Academic Publishing.

Dang, H.-A. H., \& Serajuddin, U. (2020). Tracking the sustainable development goals: emerging measurement challenges and further reflections. World Bank Working Paper.

Deaton, A. (2008). Income, health, and well-being around the world: evidence from the gallup World poll. Journal of Economic Perspectives.

Diener, E., \& Seligman, M. E. (2004). Beyond money: toward an economy of well-being. Psychological science in the public interest.

Diener, E., Sandvik, E., Seidlitz, L. et al. The relationship between income and subjective well-being: Relative or absolute?. Soc Indic Res 28, 195-223 (1993). https://doi.org/10.1007/BF01079018

Everett, T., Ishwaran, M., Ansaloni, G. P., \& Rubin, A. (2010). Economic Growth and the Environment. Defra Evidence and Analysis Series, Munich Personal RePEc Archive.

Frey, Bruno S. and Stutzer, Alois.(2010). Happiness and Economics: How the Economy and Institutions Affect Human Well-Being, Princeton: Princeton University Press. https://doi.org/10.1515/9781400829262

Frey, Bruno, S., and Alois Stutzer, (2002). What can economists learn from happiness research? Journal of Economic Literature, 40 (2): $402-$ 435.DOI: 10.1257/002205102320161320

Global Footprint Network. (2020). Ecological Footprint data.

International Monetary Fund. (2021). World Economic Outlook.

International Monetary Fund. (2020). Gross Domestic Product: An Economy's All.

Layard, R. (2005). Happiness: lessons from a new science. Happiness: lessons from a new science, foreign affairs (Council on Foreign Relations) 84(6), DOI: 10.2307/20031793

Luan, Z., \& Zhou, Z. (2017). The relationship between annual GDP growth and income inequality, Georgia Institute of Technology.

Millimet, D., \& Stengos, T. (2003). The environmental kuznets curve: real progress or misspecified models? The Review of Economics and Statistics.

Denmark-Ministry of Health. (2017). Healthcare in Denmark.

New Economic Foundation. (2020). Happy Planet Index.

OECD. (2001). Gross Domestic Product.

Oswald, A. J. (1997). Happiness and Economic Performance. The Economic Journal, Vol. 107, No. 445 (Nov., 1997), pp. 1815-1831, Oxford University Press

Oxfam International. (2020). India: extreme inequality in numbers.

Smith, A. (1776). An Inquiry into the Nature and Causes of Wealth of Nations.

Stevenson, B., \& Wolfers, J. (2008). Economic growth and subjective well-being: reassessing the easterlin paradox.

(2008). The Production Accounts. The System of National Accounts.

The Social Progress Imperative. (2020). Social progress. 
Transparency International. (2020). Corruption Perception Index.

U.S. Bureau of Economic Analysis. (2019). Gross Domestic Product.

United Nations Sustainable Development Solutions Network. (2018). World Happiness Report.

United Nations Sustainable Development Solutions Network. (2020). World Happiness Report.

Vásquez, I., \& McMahon, F. (2020). The Human Freedom Index.

Voukelatou, V., Gabrielli, L., Miliou, I. et al. Measuring objective and subjective well-being: dimensions and data sources. Int J Data Sci Anal 11, 279-309 (2021). https://doi.org/10.1007/s41060-020-00224-2

White, A. G. (2020). Satisfaction with Life Index Report

Esteban Ortiz-Ospina and Max Roser (2013) - "Happiness and Life Satisfaction". Published online at OurWorldInData.org. Retrieved from: 'https://ourworldindata.org/happiness-and-life-satisfaction'

Williams, J. (2014). The Environmental Kuznets Curve. The Earthbound Report., https://earthbound.report/2014/03/11/the-environmentalkuznets-curve/

World Bank. (2019). GDP ranking.

World Bank. (2020). India overview.

World Bank. (2020). Romania overview.

World Bank. (2020). The Gini index.

World Bank. (2021). Costa Rica overview.

World Health Organization. (2020). GHE: Life expectancy and healthy life expectancy. Worldometer. 